\title{
Spillovers and Dynamic Correlations between REITs, Exchange Rates, and Equities in Japan
}

\author{
Chikashi Tsuji ${ }^{1}$ \\ ${ }^{1}$ Faculty of Economics, Chuo University, Tokyo, Japan \\ Correspondence: Chikashi Tsuji, Professor, Faculty of Economics, Chuo University, 742-1 Higashinakano, \\ Hachioji-shi, Tokyo 192-0393, Japan. E-mail: mail_sec_low@minos.ocn.ne.jp
}

Received: September 15, 2021

Accepted: September 25, 2021

Online Published: September 26, 2021

doi:10.5430/afr.v10n4p13

URL: https://doi.org/10.5430/afr.v10n4p13

\begin{abstract}
This paper investigates return transmission, volatility spillovers, and dynamic correlations between the Tokyo Stock Exchange (TSE) Real Estate Investment Trust (REIT) index, the Nikkei 225 index, and the yen/dollar exchange rate. As a result, we find many new findings and these all show our significant contributions as follows. First, there is return transmission from the Nikkei 225 to the TSE REIT index. Second, there is bidirectional return transmission between the Nikkei 225 and the yen/dollar exchange rate. Third, there are bidirectional volatility spillovers between the Nikkei 225 and the TSE REIT index. Fourth, there are volatility spillovers from the Nikkei 225 to the yen/dollar exchange rate. Fifth, dynamic conditional correlations (DCCs) between TSE REIT returns and Nikkei 225 returns are not low. Moreover, DCCs between Nikkei 225 returns and yen/dollar exchange rate changes are not high. Furthermore, DCCs between TSE REIT returns and yen/dollar exchange rate changes are quite low. These our new findings shall be useful for not only deepening our understanding of financial markets but also our related future research.
\end{abstract}

Keywords: DCC-MGARCH model, dynamic conditional correlation, exchange rate, Japanese stock market, REIT, return transmission, spillover

\section{Introduction}

On the back of increasing global financial market integrations, the nexuses between financial markets have recently been the subject of investigation (e.g., Diebold and Yilmaz, 2009; Sadorsky, 2012; Tsuji, 2019; Ahmed, 2021; Schertler and Moch, 2021). However, most existing research has been conducted by mainly focusing on equity markets, and thus there are few previous studies of spillovers and dynamic correlations between financial markets by concentrating on real estate investment trusts (REITs). In addition, we stress that there is little research of spillovers and dynamic correlations by focusing on Japanese financial markets. Therefore, investigating dynamic interactions and correlations with particular emphasis on Japanese REITs is highly significant and valuable.

Based on this motivation and considering the importance of multivariate generalized autoregressive conditional heteroscedasticity (MGARCH) model (e.g., Bollerslev et al., 1988; Engle and Kroner, 1995; Engle, 2002; Tsuji, 2017a, 2017b, 2020), this study attempts to reveal the recent situation of return transmission, volatility spillovers, and dynamic correlations between the Tokyo Stock Exchange (TSE) Real Estate Investment Trust (REIT) index, the Nikkei 225 index, and the yen/dollar exchange rate by using a trivariate vector autoregressive (VAR)(3)-dynamic conditional correlation (DCC)-spillover-MGARCH model. As a result, we find new many beneficial findings, and these all demonstrate our significant contributions as follows.

First, (1) there is return transmission from the Nikkei 225 to the TSE REIT index. Second, (2) there is bidirectional return transmission between the Nikkei 225 and the yen/dollar exchange rate. Third, (3) there are bidirectional volatility spillovers between the Nikkei 225 and the TSE REIT index. Fourth, (4) there are volatility spillovers from the Nikkei 225 to the yen/dollar exchange rate. Fifth, (5) DCCs between TSE REIT returns and Nikkei 225 returns are not low. Moreover, (6) DCCs between Nikkei 225 returns and yen/dollar exchange rate changes are not high. Finally, (7) DCCs between TSE REIT returns and yen/dollar exchange rate changes are quite low. These new findings derived from our study shall be helpful for advancing our understanding of financial market linkages. Regarding the organization of this paper, Section 2 provides a literature review; Section 3 explains our data and variables; and Section 4 describes our model. Section 5 presents the results; and Section 6 concludes the paper. 


\section{Literature Review}

This section concisely reviews the previous studies. First, as regards spillover research, Diebold and Yilmaz (2009) provided separate measures of return transmission and volatility spillovers using 19 global stock market data. Elsewhere, Sadorsky (2012) analyzed volatility spillovers between clean energy and technology equity indices and oil futures. After these, focusing on BRICS (Brazil, Russia, India, China, and South Africa) countries, Boubaker and Raza (2017) investigated spillover effects between oil and stock markets. Further, Roy and Roy (2017) investigated volatility spillover effects between gold and commodity futures, equities, bonds, and exchange rates by concentrating on Indian financial markets.

Later, Tsuji (2020) quantitatively analyzed return transmission and volatility spillover effects between banking sector equities of the US and eight other international countries. More recently, Ahmed (2021) investigated monetary policy spillovers using 46 international countries data. Furthermore, also using international data, Schertler and Moch (2021) examined spillover effects of sovereign rating events on bank equity prices. We note that these existing spillover studies do not include REITs.

Next, reviewing existing studies of REITs, first, Huerta-Sanchez et al. (2020) examined price bubbles in US REITs classified by property types. In addition, Ryu et al. (2021) empirically examined the weak-form efficient market hypothesis for US REITs. Further, Odusami (2021a) investigated the roles of jumps in US REIT returns. Moreover, Odusami (2021b) computed and examined the Value-at-Risk of US REITs using realized volatility jump models.

In addition, Gholipour et al. (2021) investigated price responses of US REIT and commercial property indices to economic uncertainties. Furthermore, Coën and Desfleurs (2021) investigated the accuracy and bias of financial analysts' forecasts, and analyzed green and non-green US REITs' abnormal earnings announcement returns. As the above literature review suggests, there is little existing research of spillovers that focused on REITs.

Table 1. Summary statistics for returns of the TSE REIT index and the Nikkei 225 index and changes of the yen/dollar exchange rate

\begin{tabular}{llll}
\hline & LRREIT & LRNK & LREX \\
\hline Mean & 0.0273 & 0.0327 & 0.0054 \\
Maximum & 12.8848 & 7.7314 & 3.7509 \\
Minimum & -20.4661 & -11.1534 & -3.1146 \\
Standard deviation & 1.1779 & 1.2918 & 0.5542 \\
Skewness & -1.2866 & -0.4584 & 0.1351 \\
Kurtosis & 52.6252 & 8.9367 & 6.9352 \\
ADF test statistic & -34.0768 & -37.3650 & -56.1064 \\
$p$-value & 0.0000 & 0.0000 & 0.0001
\end{tabular}

Notes: All the three series are daily log difference percentage returns (changes) with 2979 observations. ADF denotes augmented Dickey-Fuller.

\section{Data and Variables}

This section explains the data and variables for our study. We examine three daily log returns (changes). First is (1) the daily log percentage return of the TSE REIT index in Japan, which is denoted by LRREIT; second is (2) the daily log percentage return of the Nikkei Stock Average, the so-called Nikkei 225, which is denoted by LRNK; and third is (3) the daily log percentage change of the yen/dollar exchange rate, which is denoted by LREX. Our sample period for these three series is from April 8, 2010 through to September 7, 2021. Price and return series of these three are shown in Figure 1 and 2, respectively. From Figure 1, we understand that prices of the TSE REIT index and Nikkei 225 dropped at the time of the COVID-19 crisis, while in the yen/dollar exchange rates, such a series discontinuity is not seen. Further, from Figure 2, we also understand that in the return series of the TSE REIT index, a large structural break during the COVID-19 crisis can be seen.

Table 1 shows the summary statistics for our three log return (change) variables, LRREIT, LRNK, and LREX. Table 1 indicates that for our sample period, the mean log return (change) is the highest in LRNK while it is the lowest in LREX. In addition, Table 1 also shows that for our sample period, the volatility is the highest also in LRNK while the volatility is also the lowest in LREX. 
Panel A. TSE REIT index prices

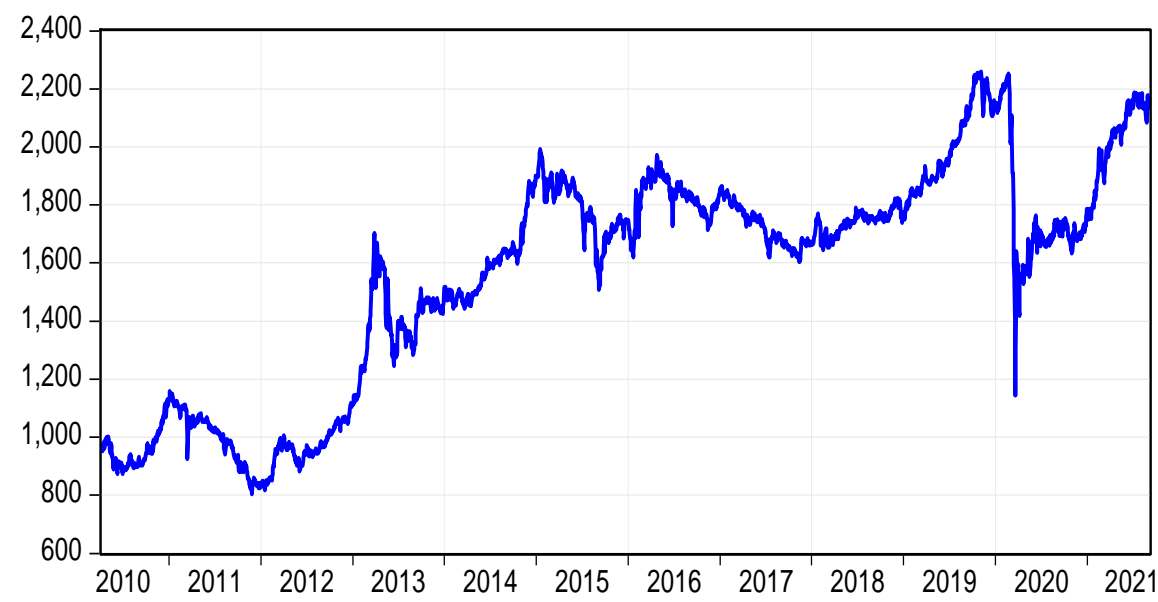

Panel B. Nikkei 225 prices

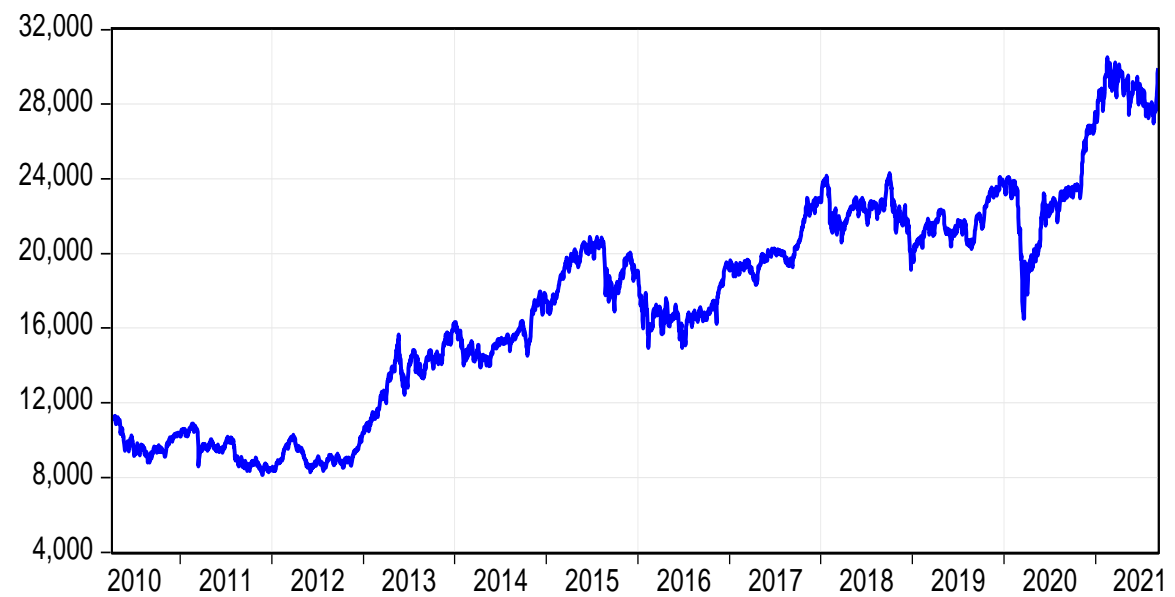

Panel C. Yen/dollar exchange rates

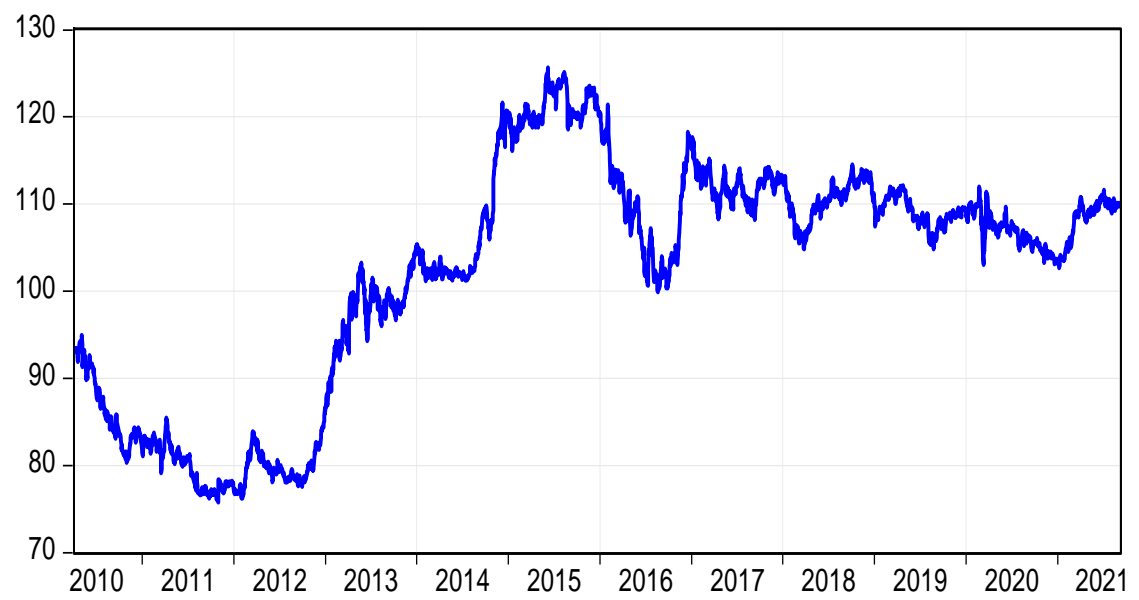

Figure 1. Time-series evolution for prices of the TSE REIT index and the Nikkei 225 index and the yen/dollar exchange rates 
Panel A. TSE REIT index returns

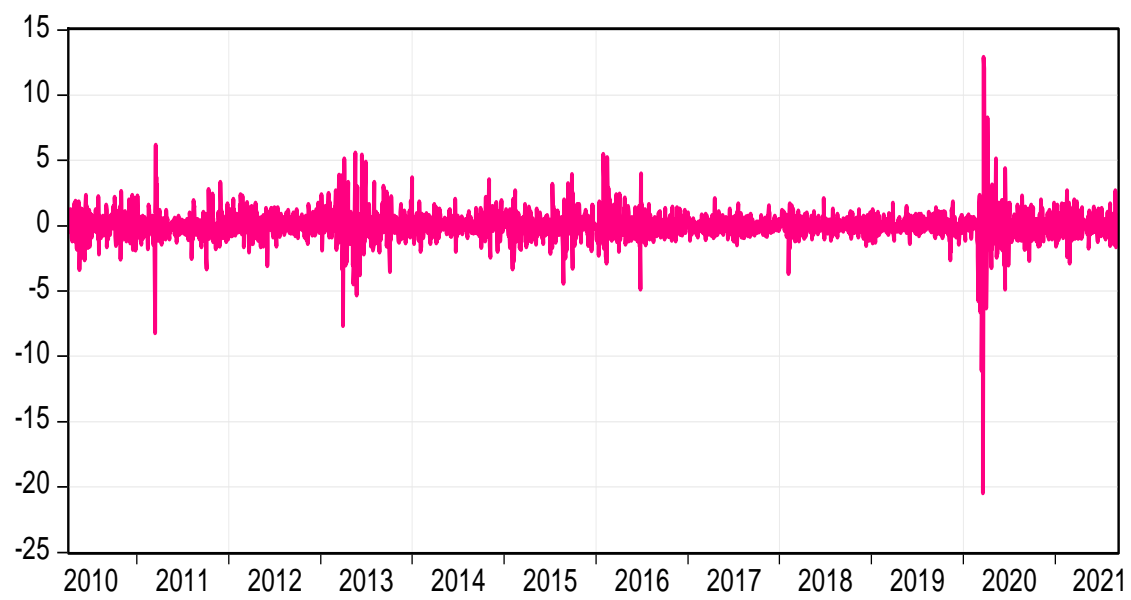

Panel B. Nikkei 225 returns

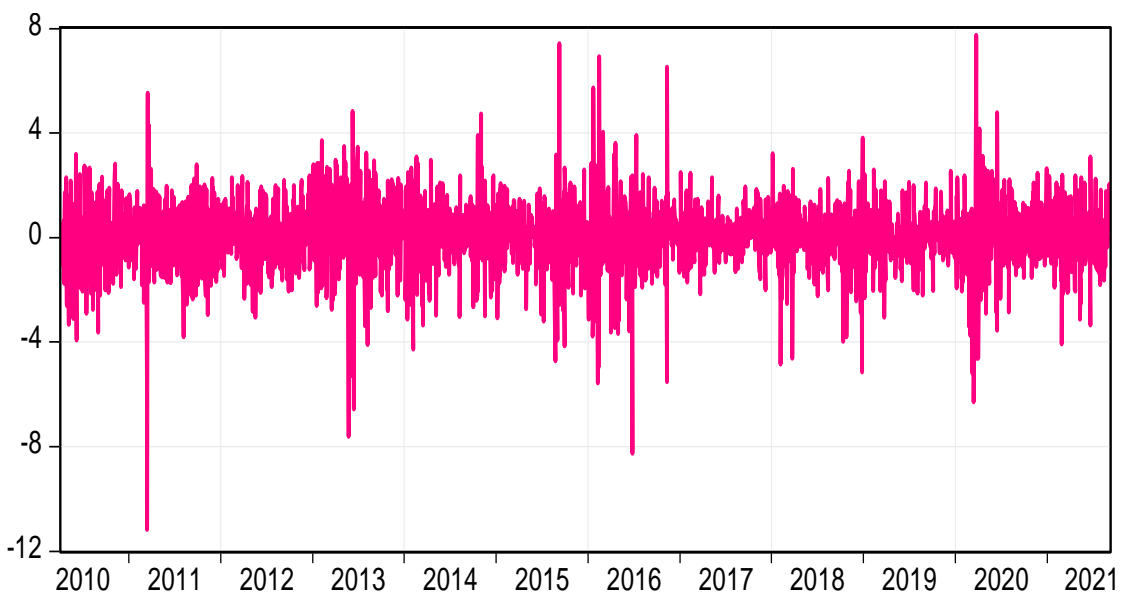

Panel C. Yen/dollar exchange rate changes

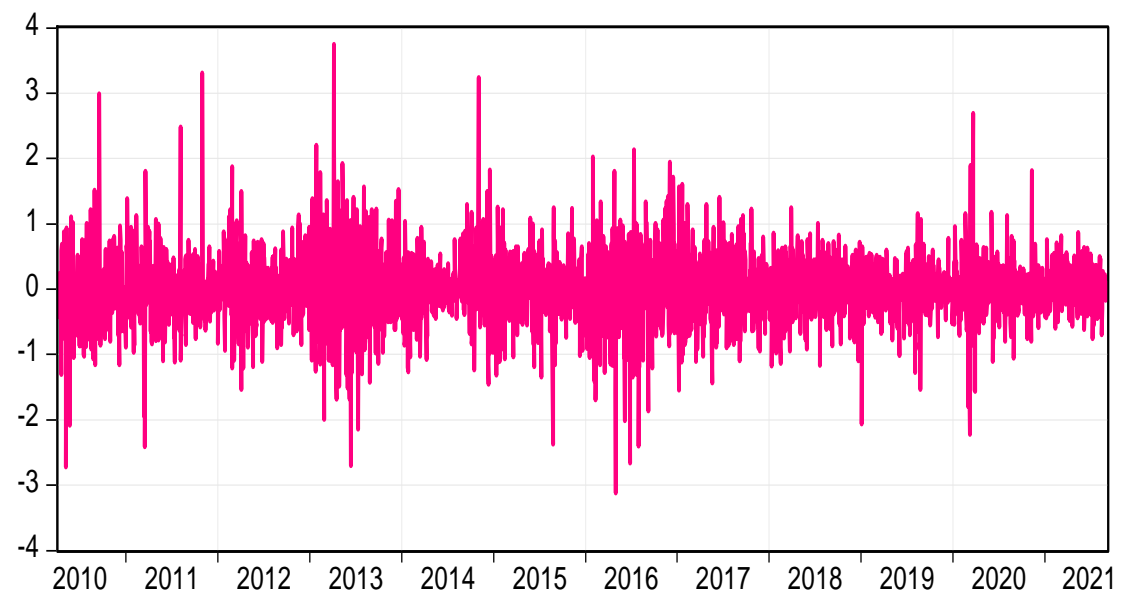

Figure 2. Time-series evolution for returns of the TSE REIT index and the Nikkei 225 index and changes of the yen/dollar exchange rate 
Table 2. Estimation results of the trivariate VAR(3)-DCC-spillover-MGARCH model for returns of the TSE REIT index and the Nikkei 225 index and changes of the yen/dollar exchange rate

\begin{tabular}{|c|c|c|c|c|}
\hline \multicolumn{5}{|c|}{ Panel A. Mean equations } \\
\hline \multicolumn{5}{|c|}{ Mean equation for LRREIT } \\
\hline Parameters & Estimates & Standard error & $t$-statistic & $p$-value \\
\hline$w_{1,1,1}$ & 0.0054 & 0.0182 & 0.2983 & 0.7655 \\
\hline$w_{1,1,2}$ & -0.0120 & 0.0191 & -0.6265 & 0.5310 \\
\hline$w_{1,1,3}$ & $-0.0692 * * *$ & 0.0172 & -4.0324 & 0.0001 \\
\hline$w_{1,2,1}$ & $0.0316 * *$ & 0.0135 & 2.3355 & 0.0195 \\
\hline$w_{1,2,2}$ & $0.0342 * * *$ & 0.0127 & 2.7066 & 0.0068 \\
\hline$w_{1,2,3}$ & -0.0046 & 0.0126 & -0.3643 & 0.7156 \\
\hline$w_{1,3,1}$ & 0.0374 & 0.0268 & 1.3955 & 0.1629 \\
\hline$w_{1,3,2}$ & 0.0160 & 0.0273 & 0.5843 & 0.5590 \\
\hline$w_{1,3,3}$ & -0.0042 & 0.0240 & -0.1737 & 0.8621 \\
\hline$w_{1,0}$ & $0.0428 * * *$ & 0.0120 & 3.5570 & 0.0004 \\
\hline \multicolumn{5}{|c|}{ Mean equation for LRNK } \\
\hline Parameters & Estimates & Standard error & $t$-statistic & $p$-value \\
\hline$w_{2,1,1}$ & $0.0417 *$ & 0.0231 & 1.8063 & 0.0709 \\
\hline$w_{2,1,2}$ & 0.0062 & 0.0231 & 0.2683 & 0.7885 \\
\hline$w_{2,1,3}$ & $-0.0364 *$ & 0.0189 & -1.9227 & 0.0545 \\
\hline$w_{2,2,1}$ & $-0.0950 * * *$ & 0.0188 & -5.0438 & 0.0000 \\
\hline$w_{2,2,2}$ & 0.0164 & 0.0189 & 0.8661 & 0.3864 \\
\hline$w_{2,2,3}$ & -0.0115 & 0.0165 & -0.6961 & 0.4864 \\
\hline$w_{2,3,1}$ & $0.1986 * * *$ & 0.0360 & 5.5123 & 0.0000 \\
\hline$w_{2,3,2}$ & -0.0210 & 0.0395 & -0.5306 & 0.5957 \\
\hline$w_{2,3,3}$ & $0.0577 *$ & 0.0339 & 1.7036 & 0.0885 \\
\hline$w_{2,0}$ & $0.0631 * * *$ & 0.0166 & 3.7924 & 0.0001 \\
\hline \multicolumn{5}{|c|}{ Mean equation for LREX } \\
\hline Parameters & Estimates & Standard error & $t$-statistic & $p$-value \\
\hline$w_{3,1,1}$ & 0.0069 & 0.0107 & 0.6511 & 0.5150 \\
\hline$w_{3,1,2}$ & -0.0052 & 0.0102 & -0.5069 & 0.6123 \\
\hline$w_{3,1,3}$ & -0.0002 & 0.0097 & -0.0222 & 0.9823 \\
\hline$w_{3,2,1}$ & $0.0859 * * *$ & 0.0084 & 10.1652 & 0.0000 \\
\hline$w_{3,2,2}$ & $0.0255^{* * *}$ & 0.0078 & 3.2547 & 0.0011 \\
\hline$w_{3,2,3}$ & -0.0003 & 0.0078 & -0.0394 & 0.9686 \\
\hline$w_{3,3,1}$ & $-0.1192 * * *$ & 0.0190 & -6.2634 & 0.0000 \\
\hline$w_{3,3,2}$ & -0.0178 & 0.0185 & -0.9633 & 0.3354 \\
\hline$w_{3,3,3}$ & -0.0228 & 0.0160 & -1.4260 & 0.1539 \\
\hline$w_{3,0}$ & 0.0078 & 0.0084 & 0.9353 & 0.3497 \\
\hline \multicolumn{5}{|c|}{ Panel B. Variance equations } \\
\hline Parameters & Estimates & Standard error & $t$-statistic & $p$-value \\
\hline
\end{tabular}




\begin{tabular}{lllll}
\hline$c_{1}$ & $0.0152 * * *$ & 0.0057 & 2.6925 & 0.0071 \\
$c_{2}$ & $0.0669 * * *$ & 0.0114 & 5.8638 & 0.0000 \\
$c_{3}$ & $0.0069 * * *$ & 0.0020 & 3.3995 & 0.0007 \\
$a_{1,1}$ & $0.1767 * * *$ & 10.7673 & 0.0000 \\
$a_{1,2}$ & 0.0164 & 6.0638 & 0.0000 \\
$a_{1,3}$ & $0.0293 * * *$ & 0.0048 & 0.6275 & 0.5303 \\
$a_{2,1}$ & 0.0113 & 0.0180 & 2.6891 & 0.0072 \\
$a_{2,2}$ & $0.0193 * * *$ & 0.0072 & 9.5218 & 0.0000 \\
$a_{2,3}$ & $0.0902 * * *$ & 0.0095 & -0.2258 & 0.8214 \\
$a_{3,1}$ & -0.0062 & 0.0276 & 1.6733 & 0.0943 \\
$a_{3,2}$ & $0.0023 *$ & 0.0014 & 4.5901 & 0.0000 \\
$a_{3,3}$ & $0.0061 * * *$ & 0.0013 & 7.1260 & 0.0000 \\
$b_{1}$ & $0.0767 * * *$ & 0.0108 & 46.6880 & 0.0000 \\
$b_{2}$ & $0.7774 * * *$ & 0.0167 & 65.0156 & 0.0000 \\
$b_{3}$ & $0.8596 * * *$ & 0.0132 & 46.5096 & 0.0000
\end{tabular}

Panel C. DCC component

$\begin{array}{lllll}\text { Parameters } & \text { Estimates } & \text { Standard error } & t \text {-statistic } & p \text {-value } \\ \alpha & 0.0187 * * * & 0.0041 & 4.5871 & 0.0000 \\ \beta & 0.9656 * * * & 0.0080 & 120.1746 & 0.0000\end{array}$

Notes: ***,**, and $*$ denote the statistical significance at the $1 \%, 5 \%$, and $10 \%$ levels, respectively. $\alpha$ and $\beta$ are the parameters of the DCC component of our model.

\section{Model}

We next document our analyzing model. Namely, the trivariate VAR(3)-DCC-spillover-MGARCH model we use in this study is as follows:

$$
\begin{gathered}
r_{i, t}=w_{i, 0}+\sum_{j=1}^{3} w_{i, j, 1} r_{j, t-1}+\sum_{j=1}^{3} w_{i, j, 2} r_{j, t-2}+\sum_{j=1}^{3} w_{i, j, 3} r_{j, t-3}+\varepsilon_{i, t} \text { for } i=1,2,3, \\
\sigma_{i, t}^{2}=c_{i}+\sum_{j=1}^{3} a_{i, j} \varepsilon_{j, t-1}^{2}+b_{i} \sigma_{i, t-1}^{2} \text { for } i=1,2,3 .
\end{gathered}
$$

To examine dynamic interactions and correlations between our three variables, LRREIT, LRNK, and LREX, this study uses a trivariate model. Other than the DCC part, our model has mean and variance equations, i.e., Eqs. (1) and (2), respectively. As shown in Eq. (1), our mean equation employs a VAR model with one to three lags to test the return transmission effects between our three variables within past three days. The return transmission effect is captured by the parameter $w_{i, j, 1}, w_{i, j, 2}$, and $w_{i, j, 3}$ in Eq. (1). In addition, as shown in Eq. (2), our variance equation specifies an MGARCH model to examine the effects of spillovers and past time-varying variances. Explaining the variables in our model, in Eq. (1), $r_{i, t}\left(r_{j, t-p}\right)$ denotes the return $i$ at time $t$ (return $j$ at time $t-p$ ), where $p=1,2,3$. $\varepsilon_{i, t}$ is the residuals for return $i$ at time $t$. In Eq. (2), $\sigma_{i, t}\left(\sigma_{i, t-1}\right)$ is the conditional volatility for return $i$ at time $t$ (at time $t-1$ ), and $\varepsilon_{j, t-1}$ is the residuals for return $j$ at time $t-1$.

Notably, as specified in Eq. (2), we capture the volatility spillover effects between our three series with the parameter $a_{i, j}$. That is, a positive value of this parameter indicates that there are volatility spillovers from series $j$ to series $i$. We note that this model structure for specifically capturing volatility spillover effects is not available in standard popular MGARCH models; hence our model specification incorporating the spillover effect in Eq. (2) should be quite valuable. We also note that the previous days' volatility effects on their own current volatilities, i.e., the GARCH effect, are captured by the parameter $b_{i}$ in our Eq. (2). 
Table 3. Summary statistics for DCCs between returns of the TSE REIT index and the Nikkei 225 index and changes of the yen/dollar exchange rate

\begin{tabular}{llll}
\hline & LRREIT and LRNK & LRREIT and LREX & LRNK and LREX \\
\hline Mean & 0.4141 & 0.0630 & 0.3362 \\
Standard deviation & 0.0900 & 0.0869 & 0.1081 \\
Mnimum & 0.1644 & -0.1971 & -0.0477 \\
Maximum & 0.8106 & 0.4412 & 0.6004
\end{tabular}

Notes: All the three series are daily DCCs with 2976 observations.

\section{Results}

\subsection{Return Transmission}

First, we explain the results of return transmission. As Panel A of Table 2 shows, (1) the statistically significant positive parameters of $w_{1,2,1}$ and $w_{1,2,2}$ indicate that the first and second lags of Nikkei 225 returns transmit to current returns of the TSE REIT index. This panel also shows that (2) the statistically significant positive parameter of $w_{2,3,1}$ shows that the first lags of the yen/dollar exchange rate changes transmit to current returns of the Nikkei 225. This panel also indicates that (3) there is weak return transmission from the first lags of TSE REIT returns to current returns of the Nikkei $225\left(w_{2,1,1}\right)$.

Moreover, as Panel A of Table 2 also presents, (4) the statistically significant positive parameters of $w_{3,2,1}$ and $w_{3,2,2}$ shows that the first and second lags of Nikkei 225 returns transmit to current changes of the yen/dollar exchange rate. Furthermore, also from Panel A of Table 2, we understand that (5) there is no return transmission from the yen/dollar exchange rate to the TSE REIT, and (6) there is no return transmission from the TSE REIT to the yen/dollar exchange rate.

\subsection{Volatility Spillovers}

Next, we document the results of volatility spillovers. As Panel B of Table 2 shows, (1) the statistically significant positive parameter of $a_{1,2}$ means that the first lags of return shocks to the Nikkei 225 spill over to current volatilities of the TSE REIT index. This panel also shows that (2) the statistically significant positive parameter of $a_{2,1}$ indicates that the first lags of return shocks to the TSE REIT spill over to current volatilities of the Nikkei 225. This panel also indicates that (3) there are weak volatility spillovers from the TSE REIT to the yen/dollar exchange rate $\left(a_{3,1}\right)$.

In addition, as Panel B of Table 2 also exhibits, (4) the statistically significant positive parameter of $a_{3,2}$ indicates that the first lags of return shocks to the Nikkei 225 spill over to current volatilities of the yen/dollar exchange rate. Furthermore, also from Panel B of Table 2, we understand that (5) there is no volatility spillover from the yen/dollar exchange rate to the TSE REIT, and (6) there is no volatility spillover from the yen/dollar exchange rate to the Nikkei 225. We also understand that from this panel, all the GARCH effects for the three series are statistically significant $\left(b_{1}, b_{2}\right.$, and $\left.b_{3}\right)$.

\subsection{Dynamic Correlations}

Finally, we explain the results of DCCs between our three series. Figure 3 plots DCCs between TSE REIT index returns, Nikkei 225 index returns, and yen/dollar exchange rate changes. In addition, Table 3 exhibits the summary statistics for three DCCs. As Panel A of Figure 3 and Table 3 present, DCCs between TSE REIT returns and Nikkei 225 returns are not low, indicating that the risk diversification effects obtained by using these two assets are not so high. In addition, we should note that during the recent COVID-19 crisis, DCCs between the TSE REIT and the Nikkei 225 jumped to around 0.8 .

Moreover, Panel C of Figure 3 and Table 3 also show that DCCs between Nikkei 225 returns and yen/dollar exchange rate changes are not high, meaning that the risk diversification effects obtained by using Japanese equities denominated in yen and another-class asset denominated in US dollars would be not low. Furthermore, Panel B of Figure 3 and Table 3 also show that DCCs between TSE REIT returns and yen/dollar exchange rate changes are quite low, suggesting that the risk diversification effects obtained by using Japanese REITs denominated in yen and another-class asset denominated in US dollars would be rather high. 
Panel A. TSE REIT index returns and Nikkei 225 returns

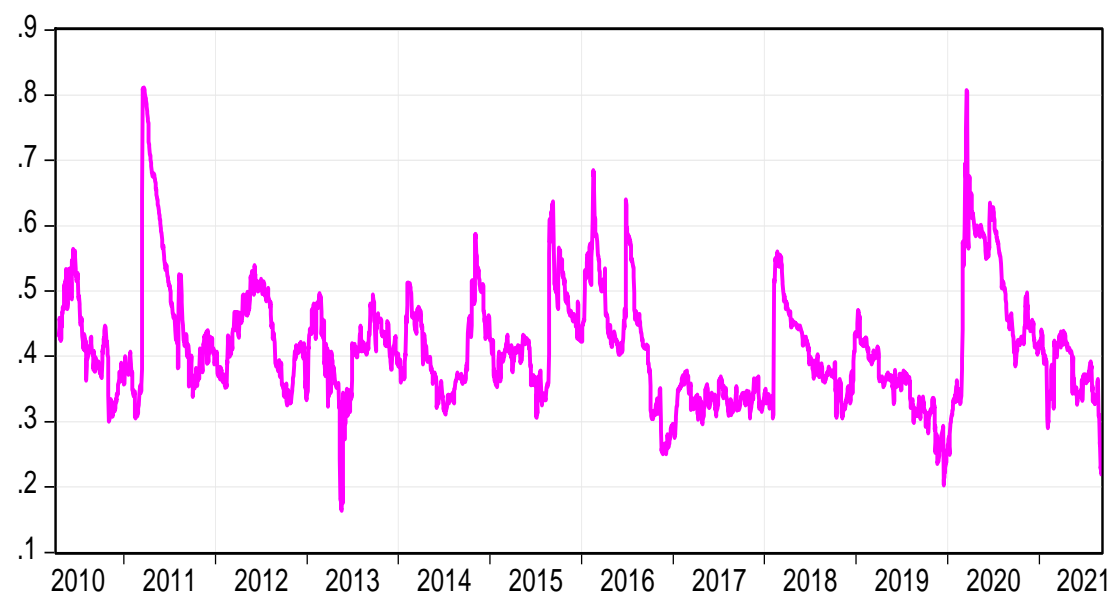

Panel B. TSE REIT index returns and yen/dollar exchange rate changes

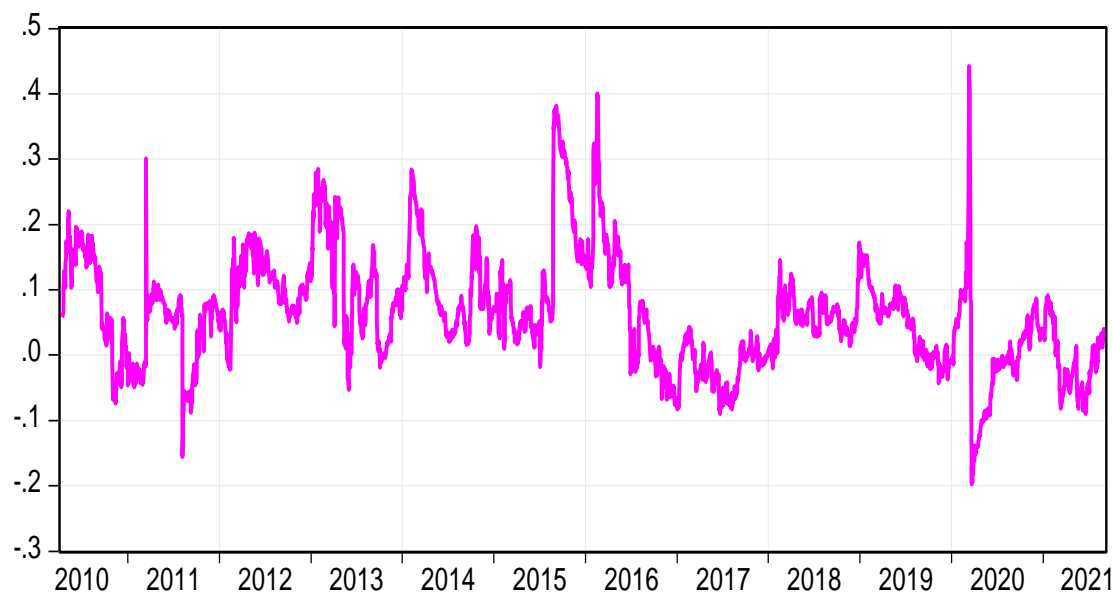

Panel C. Nikkei 225 returns and yen/dollar exchange rate changes

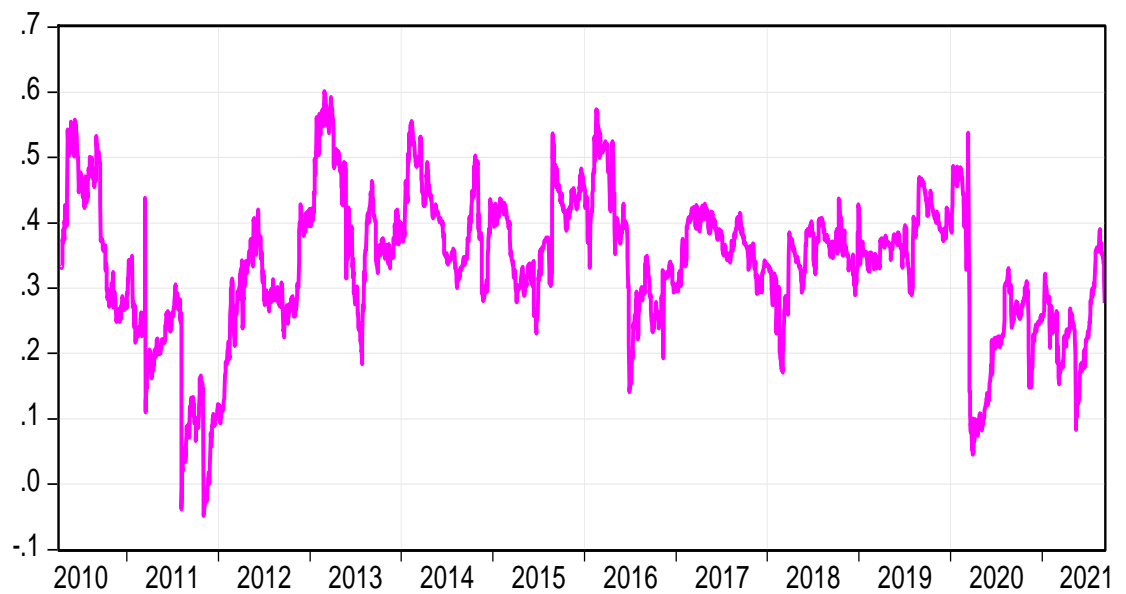

Figure 3. Dynamic conditional correlations between TSE REIT index returns, Nikkei 225 index returns, and yen/dollar exchange rate changes 


\section{Conclusions}

Using daily time-series data comprising the period of the recent COVID-19 crisis, this study examined return transmission, volatility spillovers, and dynamic correlations between the TSE REIT index, the Nikkei 225 index, and the yen/dollar exchange rate. As a result, we found many new interesting findings, and these all demonstrate our significant contributions, which we clearly documented in the introductory section.

We consider that these new findings derived from our study shall be helpful for not only academic researchers but also industrial practitioners to deepen the understanding of the effects of return transmission, volatility spillovers, and dynamic correlations between REITs, equities, and exchange rates. Hence our demonstrations and illustrations conducted in this paper should be highly useful for future studies, thus extending this line of research is one of my future works.

\section{Acknowledgements}

The author greatly appreciates this journal for the repeated kind article invitations. The author also thanks Sarah Chen for her kind editorial assistance to this paper. Furthermore, the author thanks anonymous reviewers for their supportive comments on this paper. Moreover, I also appreciate a Grant-in-Aid for Scientific Research from the Japan Society for the Promotion of Science and the Chuo University Personal Research Grant for the generous financial assistance to this research. Finally, I deeply thank all the Editors of this journal for their kind attention and skillful editorship of my paper.

\section{References}

Ahmed, R. (2021). Monetary policy spillovers under intermediate exchange rate regimes. Journal of International Money and Finance, 112, 102342. https://doi.org/10.1016/j.jimonfin.2020.102342

Bollerslev, T., Engle, R. F., \& Wooldridge, J. M. (1988). A capital asset pricing model with time-varying covariances. Journal of Political Economy, 96, 116-131. https://doi.org/10.1086/261527

Boubaker, H., \& Raza, S. A. (2017). A wavelet analysis of mean and volatility spillovers between oil and BRICS stock markets. Energy Economics, 64, 105-117. https://doi.org/10.1016/j.eneco.2017.01.026

Coën, A., \& Desfleurs, A. (2021). The relative performance of green REITs: Evidence from financial analysts' forecasts and abnormal returns. Finance Research Letters, forthcoming. https://doi.org/10.1016/j.frl.2021.102163

Diebold, F. X., \& Yilmaz, K. (2009). Measuring financial asset return and volatility spillovers, with application to global equity markets. The Econometrics Journal, 119, 158-171.

Engle, R. F. (2002). Dynamic conditional correlation: A simple class of multivariate generalized autoregressive conditional heteroskedasticity models. Journal of Business \& Economic Statistics, 20, 339-350. http://dx.doi.org/10.1198/073500102288618487

Engle, R. F., \& Kroner, K. F. (1995). Multivariate simultaneous generalized Arch. Econometric Theory, 11, $122-150$. https://doi.org/10.1017/S0266466600009063

Gholipour, H. F., Tajaddini, R., Farzanegan, M. R., \& Yam, S. (2021). Responses of REITs index and commercial property prices to economic uncertainties: A VAR analysis. Research in International Business and Finance, 58, 101457. https://doi.org/10.1016/j.ribaf.2021.101457

Huerta-Sanchez, D., Jafarinejad, M., Kim, D., \& Soyeh, K. W. (2020). Disentangling bubbles in equity REITs. The Quarterly Review of Economics and Finance, 76, 357-367. https://doi.org/10.1016/j.qref.2019.09.007

Odusami, B. O. (2021a). Volatility jumps and their determinants in REIT returns. Journal of Economics and Business, 113, 105943. https://doi.org/10.1016/j.jeconbus.2020.105943

Odusami, B. O. (2021b). Forecasting the Value-at-Risk of REITs using realized volatility jump models. North American Journal of Economics and Finance, 58, 101426. https://doi.org/10.1016/j.najef.2021.101426

Roy, R. P., \& Roy, S. S. (2017). Financial contagion and volatility spillover: An exploration into Indian commodity derivative market. Economic Modelling, 67, 368-380. https://doi.org/10.1016/j.econmod.2017.02.019

Ryu, I., Jang, H., Kim, D., \& Ahn, K. (2021). Market efficiency of US REITs: A revisit. Chaos, Solitons and Fractals, 150, 111070. https://doi.org/10.1016/j.chaos.2021.111070

Sadorsky, P. (2012). Correlations and volatility spillovers between oil prices and the stock prices of clean energy and technology companies. Energy Economics, 34, 248-255. https://doi.org/10.1016/j.eneco.2011.03.006 
Schertler, A., \& Moch, N. (2021). Bank foreign assets, government support and international spillover effects of sovereign rating events on bank stock prices. Journal of Banking and Finance, $130,106187$. https://doi.org/10.1016/j.jbankfin.2021.106187

Tsuji, C. (2017a). Interpreting the estimates from the full VECH model with asymmetry: The case of US and Canadian equity prices. Accounting and Finance Research, 6, 236-243. https://doi.org/10.5430/afr.v6n4p236

Tsuji, C. (2017b). How can we interpret the estimates of the full BEKK model with asymmetry? The case of French and German stock returns. Business and Economic Research, 7, 342-351. https://doi.org/10.5296/ber.v7i2.12071

Tsuji, C. (2019). Structural breaks and volatility spillovers: The case of the US and Canadian stock markets. Journal of Management Research, 11, 30-44. https://doi.org/10.5296/jmr.v11i2.14513

Tsuji, C. (2020). Correlation and spillover effects between the US and international banking sectors: New evidence and implications for risk management. International Review of Financial Analysis, 70, 101392. https://doi.org/10.1016/j.irfa.2019.101392

\section{Copyrights}

Copyright for this article is retained by the author(s), with first publication rights granted to the journal.

This is an open-access article distributed under the terms and conditions of the Creative Commons Attribution license (http://creativecommons.org/licenses/by/4.0/). 